\section{СЕМАНТИКА МУЗИЧНОЇ МОВИ ДУХОВНИХ КАНТАТ Й. С. БАХА ПАСІОННОГО ТИПУ}

\author{
Боршуляк Альона Мирославівна \\ Кандидат мистеитвознавства, старший викладач, \\ ORCID: 0000-0002-2734-8395, \\ e-mail: alyona_bor@ukr.net, \\ Кам'янець-Подільський наиіональний \\ університет імені Івана Огієнка, \\ вул. Огієнка, 61, Кам'янеиьь-Подільський, Украӥна, 32300
}

Мета статті - проаналізувати семантичні аспекти духовних кантат Й. С. Баха пасіонного типу, виявити й розкрити їхню смислову глибину та філософсько-релігійні інспірації. Методологія дослідження базується на застосуванні фундаментальних загальнонаукових методів пізнання, а також спеціальних музикознавчих методів, зокрема аналітичного у вивченні наукової літератури; жанрово-стильового й історико-культурологічного, які сприяють встановленню закономірностей розвитку та специфіки жанру кантати як цілісного художнього об’єкта; герменевтичного методу, що допоміг осягнути філософську глибину бахівських кантат. Семантичний аналіз постає як один із головних та найбільш перспективних методів розшифрування смислових структур духовних кантат Баха пасіонного характеру. Наукова новизна полягає в розкритті семантичних аспектів духовних кантат Й. С. Баха пасіонного типу як носіїв сотеріологічної теорії, що проявляються музично-риторичними фігурами та символікою, у розширенні уявлень про символіко-риторичні принципи мислення композитора. Висновки. Завдяки семантичному аналізу музичної мови духовних кантат Й. С. Баха виявлено, що в кантатах пасіонного типу найбільш повно відобразилася бахівська інтерпретація лютеранства, а саме сотеріологічна теорія, яка розкриває вчення про спасіння. Доведено, що кантати пасіонного типу композитор будує за драматургічним принципом «від страждання до благодаті». Бах застосовує комплекс символіки пасіонності; для відтворення болю і мук Христа він часто використовує риторичну фігуру passus duriusculus як символ страждання. 3'ясовано, що занурення в смислову глибину духовних кантат Й.С. Баха пасіонного типу дає підстави по-новому розкрити багатовимірність комплексу одвічних проблем, які сприяють народженню нового сенсу.

Ключові слова: семантика; музична символіка; принцип мислення; пасіонність; сетеріологічна теорія

\title{
Вступ
}

У наш час духовні кантати Й. С. Баха не лише стали затребуваними в лютеранських богослужіннях, але й міцно вкорінилися в хоровій виконавській практиці. Кожен історичний етап вивчення бахівського спадку демонструє чергові відкриття, знаходить смислові перспективи та нові пласти змісту музичних творів. Сучасне вітчизняне мистецтвознавство активно прагне заповнити прогалину в дослідженні філософсько-релігійних аспектів творчості Баха, яка утворилася внаслідок відбиття «апостасійної тенденції історії» (Медушевский, 2003, с. 7). Актуальним завданням постають грунтовні розвідки семантики музичної мови кантат Баха та джерел його духовної інспірації.

Музична мова Й. С. Баха неодноразово ставала об'єктом дослідження і в зарубіжному, і вітчизняному музикознавстві. Досі вагомою залишається фундаментальна праця А. Швейцера (2004), де була здійснена спроба вперше дослідити музичну мову композитора. Проблема бахівської символіки цікавить видатного музикознавця, піаніста й педагога Б. Яворського (2009), який на основі дослідження кантатно-ораторіальної творчості Баха створив систему музичних символів. Слідом за Яворським пошуками втраченого смислу «Добре темперованого клавіру» займався Р. Берченко (2008). Поряд із відомими доробками, котрі належать Й. Форкелю (2008), Е. Бодки (1993), М. Друскіну (1976; 1982), Т. Лівановій (1980), варто виділити праці сучасних вітчизняних музикознавців, що присвячені духовним аспектам творчості Й. С. Баха - К. Берденникової (2008), Н. Заболотної (2002), С. Серенко (2004) та ін. Однак дослідження переважно сконцентровані навколо окремих питань.

Наукова новизна статті полягає в розкритті семантичних аспектів духовних кантат Й. С. Баха пасіонного характеру як носіїв сотеріологічної теорії, що проявляються музично-риторичними фігурами та символікою, а також у розширенні уявлень про символіко-риторичні принципи мислення композитора.

(C) Боршуляк А. М., 2020 


\section{Мета статті}

Мета статті - проаналізувати семантичні аспекти духовних кантат Й. С. Баха пасіонного типу, виявити й розкрити їхню смислову глибину та філософсько-релігійні інспірації.

Методологія дослідження. У статті використані фундаментальні загальнонаукові методи пізнання, а також спеціальні музикознавчі методи: аналітичний під час вивчення наукової літератури; жанрово-стильовий та історико-культурологічний сприяють встановленню закономірностей розвитку та специфіки жанру кантати як цілісного художнього об' єкта; герменевтичний метод допоміг осягнути філософську глибину бахівських кантат. Семантичний аналіз постає як один із головних та найбільш перспективних методів розшифрування смислових структур духовних кантат Й. Баха пасіонного типу.

\section{Виклад матеріалу дослідження}

До жанру кантати Й. С. Бах звертався протягом багатьох років, починаючи з 1707 р. Багато ранніх кантат композитор написав для особливих подій. Після призначення концертмейстером у Веймарі в березні 1715 р. Бах отримав доручення щомісячно забезпечувати церкву музикою, а після переїзду в Лейпциг Йоганн Себастьян почав писати кантати для цілого літургійного року. Цикли таких творів відомі як Jahrgange, до них увійшли й ранні кантати. Бах залишив після себе п'ять циклів кантат (біля трьохсот творів), проте майже дві п'ятих з них утрачено, деякі збереглися частково, авторство інших досить спірне.

У літургії кантата виконувалася після читання Свангелії i, зазвичай, служила інтерпретацією біблійного тексту. За слушним спостереженням Н. Шепеленко (2018) «Богоспілкування («Бог - людина») - сутнісна ознака барокової картини світу» (с. 95). Бахівські кантати можна розглядати як другу проповідь, адже тлумачення євангельських читань Бахом було дуже глибоке. Йоганну Себастьяну присвоювали багато екстравагантних титулів, таких як «перший великий німець після Лютера» і «П'ятий Євангеліст». Хоча багато істориків погоджуються з тим, що Бах був вірним і добре освіченим лютеранином, інші вважають перебільшенням приписування йому цих похвал. Німецький пастор та музикознавець В. Бланкенбург (Blankenburg, 1950) вказував на те, що називати Баха «П'ятим Євангелістом» $\epsilon$ небезпечно помилково, оскільки «його музика служить Євангелії, але не є ним» (с. 366). Однак Бланкенбург також приходить до висновку, що, незважаючи на всю свою творчість і працю, Бах насамперед був членом лютеранської церкви. 3 іншого боку, цікавою є теза Фрідріха Блума (Blume, 1963) на фестивалі Баха в червні 1962 р.: «Чи любив Бах церковну роботу? Чи була вона для нього духовною необхідністю? Навряд. Про це немає жодних свідчень. Бах, верховний кантор, творчий слуга слова божого, вірний лютеранин $є$ легендою» (с. 218).

3 того часу було проведено чимало досліджень позицій різних учених та зроблено висновки, що все ж таки вивчення музики Баха неможливо уявити без звернення до його знань лютеранства. Саме в кантатах відобразилася бахівська інтерпретація лютеранства. Згадаймо слова А. Швейцера (2004): «У порівнянні з кантатами все інше, що створив Бах, здається не більше, ніж доповнення» (с. 190). 3 цим висловлюванням можна не погодитись, але, безперечно, духовні кантати - величезна частина його спадку.

Сам Й. С. Бах не позначав свої духовні твори словом «кантата», використовуючи інші назви: «п'єca», «річ» (stuck); «діалог», «концерт», «мотет». У його розумінні визначення жанру «кантата» асоціювалось із світським жанром. Але в основі кантат часто лежить кант, який спочатку був духовним жанром і означав простий спів, властивий музиці різних християнських церков. Погодимось із думкою Н. Заболотної (2002), що кантата в своїй основі духовний твір, але вона може бути і ортодоксальною, і дещо віддаленою від церковної ортодоксії (Заболотная, 2002, с. 236).

Бахівські кантати пасіонного типу відображають релігійну доктрину, в основі якої сотеріологічна теорія. Ідея страждання, самопожертвування та спасіння, що є центральною в сотеріології, захоплює композитора. Саме через подолання земних страждань відбувається прощення через муки, а отже, спасіння. Зазначимо, що пасіонність тлумачиться як феномен, котрий перейняв властивості жанру пасіонів і трансформувався в принцип мислення, смислотворення й драматургії. Отже, проаналізуємо семантику деяких духовних кантат пасіонного характеру.

До духовних творів Баха пасіонного типу належить кантата №150 «Nach dir, Herr, verlanget mich» («До тебе я лину»), створена в перші роки веймарського періоду, вона $є$ типовою для бахівського вираження скорботи та радості. Вже в Sinfonii (вступі) з'являється «жорсткий» хроматично низхідний хід 
passus duriusculus, який пронизує майже весь твір. Цей же хід композитор застосовує для передавання трепетного страху під час звернення «до тебе я лину» в другому номері кантати. Елементи означеної теми зустрічаються ще в одному хорі - № 4. Закінчення кантати написане у формі чакони на остинатний бас. Риторична фігура passus duriusculus у висхідному русі почергово проходить у всіх голосах. Це рідкісний приклад хорової чакони, де, як відмічає Швейцер (2004), вже «відчувається рука майстра, який створив Crucifixus сі-мінорної меси» (с. 398). Але в заключному хорі остинатна тема подається у висхідному русі (тобто немов в оберненні), на відміну від Crucifixus ci-мінорної меси, що дає надію на просвітлення та життя.

Символіка пасіонності використовується і в Кантаті № 78 «Jesu, der du meine Seele» («Iсус, душа моя»), написаній у 1723 р. та виконаній 10 вересня 1724 р. в чотирнадцяту неділю після Трійці в Лейпцигу. Ця кантата належить до другого бахівського Jahrgang (річний комплект), у якому основою кантат були лютеранські гімни. Музика кантати базується на хоралі з 12 строф Йоганна Ріста та написана для хору, сурми, оркестрової флейти, двох гобоїв, двох скрипок, альта і генерал баса - як для звичайної неділі це доволі великий оркестр. Сам текст хоралу з'являється у 1, 3, 5, 7 частинах, він тісно пов'язаний з євангельською розповіддю про зцілення десяти прокажених.

Перша частина кантати найбільш велика і важлива, що типово для всіх хоральних кантат другого Jahrgang. Текст є першою строфою Рістового хоралу про спокутування людських гріхів через страждання та воскресіння Христа. Зазначена тема домінує в багатьох кантатах Баха. Ідея «спасіння як тріумфу» часто з'являється в частинах, пов'язаних із Христовими муками, вона також має суттєве значення і в першій частині кантати. У ній композитор звертається до жанру пасакалії, який часто застосовує для передавання пасіонного образу. Вступний хор витриманий у суворій манері. М. Друскін визначає його як «переповнену страждання чакону» (Друскин, 1982, с. 224), Т. Ліванова - як пасакалію (Ливанова, 1980, c. 52).

Уже в інструментальному вступі першого хору відчувається комплекс символіки пасіонності. Відразу звучить риторична фігура passus duriusculus (в басів), яка надалі поєднується із темою хреста (альт) в оберненні і неповним проведенням Dies irae в сопрано (c-b-c-a - 3 великою секундою в основі, як варіантність d-c i продовження теми $\mathrm{b}-\mathrm{g}$ ). Таке символічне поєднання свідчить про спокутування й безсмертя через страждання та муки. У друге речення оркестрового вступу Бах уводить висхідні пасажі, оспівування й ритм радості - figura corta, як символ життя, надіï, a passus duriusculus переносить у сопрано.

Основу першого хору кантати «Ісус, душа моя» складає риторична фігура passus duriusculus і в низхідному, і у висхідному русі. Цю фігуру можна знайти не лише в кантатах пасіонного характеру, але й у різдвяних, адже дорога в лютеранстві до хреста пролягає через ясла, і вже в різдвяній музиці ми знаходимо натяк на страждання та спасіння. Саме такої позиції притримувався Ю. Петров (1993), відмічаючи, що число «8», символізуючи смерть, часто можна зустріти в творах, які прославляють Христа. На перший погляд, це може здатися недоречним, але слід мати на увазі, що «вираження ідеї в її внутрішньому протиріччі якраз і було характерне для барокового мислення, відомим в старовинних естетичних теоріях під назвою «концепт» (concepto). У контексті нашого предмета вісім не що інше, як знак пророцтва» (Петров, 1993, с. 15). Отже, уже при народженні Ісуса ми маємо натяк на його подальшу долю: страждання та розп’яття.

Скорботна тема в кантаті акцентується, повторюючись 27 разів, а в поліфонічному хорі розвиваються іiї хроматичні інтонації, сопрано і валторна проводять хоральний cantus firmus. У деяких місцях Бах був змушений змінити тему чакони ритмічно, мелодично й тонально, щоб вона відповідала мелодії хоралу. Відмітимо, що число мало неабияке значення для Баха: у ньому було закладено особливий зміст, майже магічний. У творах Баха поєднуються і піфагорейська, і «сакральна» символіка, і середньовічна числова містика. Число «27» - це символічне число Єдиної Трійці, взяте 9 разів, що символізує Абсолютну достатність, матеріальний розум Всесвіту, мозок. Символічне число 27 зберігає свою важливість у багатьох творах Баха (третя частина «Clavierubung», яка має 27 частин, Meca b-moll також містить 27 частин). У названих творах та в Кантаті № 78 число 27 слід розглядати як підсилення віри через муки Христа, через його ототожнення з членами трійці. Не лише Христос переносить муки, а й уся неподільна Трійця.

Бах, добре начитаний лютеранський богослов, використав число 27 як нагадування про Лютерову теологію, що стосується відповідної неділі, адже для Лютера віра є необхідною дорогою до спасіння. У своїй проповіді для цієї неділі він пише: «Але він (Павло) також показує, звідки християни отримали силу, що дала їм змогу протистояти тілесним похотям; а саме з факту, що вони отримали Святий Дух 
через віру і знання, що у них є милостивий Господь. Тож їхні серця наповнилися любов’ю і бажанням слухатись Бога і остерігатись гріха» (Leahy, 1999, с. 33). Припущення про те, що Бах використовує число 27 навмисно як символ, підкріплюється тим фактом, що загальне число тактів у цій частині 144. Множники цього числа $(12 \times 12)$ часто з'являються в Біблії (12 родів Ізраїлю, 12 апостолів, 12 як число церков згідно з книгою Апокаліпсису). Отже, число 144 було символом обраних людей.

Лише 21 із 144 тактів першої частини не мають теми остинато. Бах будує всю частину в манері хоральної фантазії Пахельбеля. Тема й ритм «радості- відродження» супроводжують скорботний мотив протягом усього хору. Поєднавши дві протилежні музично-риторичні фігури, Бах інтерпретує Лютера, який у трактаті «Von der Freiheit eines Christenmenschen» зображує аналогом душі - наречену, а Христа як нареченого. Використання Бахом радісної теми (figura corta) в басах поряд із трагічною хроматичною лінією (passus duriusculus) дає нам відчуття прощення через муки, що підтверджує сотеріологічну теорію.

Мотив Dies irae пронизує всю частину (т. 32 - es-d-es-c у тенора, т. 44 - fis-e-fis-d в соло гобоя, т. 64 - уперше дублюється в скрипок і тенорів c-b-c-a-b-g, т. 136 - повне проведення - b-a-b-g-a-f-g та ін.). У третьому куплеті (хор побудований у куплетній формі) відбувається просвітлення й ствердження сподівань, завдяки висхідним пасажам і мотивам радості. У хорові голоси все частіше вплітаються інтервали кварти як символ прийняття волі Бога, надії та впевненості. Завершується частина музичнориторичною фігурою passus duriusculus у басовому оркестровому голосі, що переходить в оспівування та октавний хід із квартовим закінченням. У верхньому голосі звучить тема хреста в оберненні, що символізує спокутування.

Композитор проводить арку від вступного хору до заключного, в оркестровому супроводі якого частково відроджується passus duriusculus. У Бахівській глибокій теологічній інтерпретації доктрини спасіння, у першій частині Кантати № 78 закладається основа для наступних частин. Вирішення всієї неминучої тривоги досягається у фінальній частині, де завершальна строфа Рістового хоралу сприяє розумінню, що боротьба із Христовою смертю винагороджується у «der süßen Ewigkeit» (солодкій вічності).

До пасіонного типу належить рання Кантата № 21 «Ich hatte viel Bekummernis» («Я багато горя перетерпів»), написана у Веймарі в 1714 р. Кантата складається з 11 номерів, що розподіляються на дві частини. Перша частина кантати сконцентрована на одному скорботному образі: патетичний інструментальний вступ, скорботний хор, трагічно-скорботна арія «Зітхання, сльози», «сльозлива» арія тенора, заключний скорботний хор. Т. Ліванова (1980) зазначає, що в арії тенора скорбота «ллється струмками сліз» (Ливанова, 1980, с. 78). У другій частині відбувається просвітлення скорботи, яке завершується Хором із фінальними радісними юбіляціями «Alleluja» в C-dur.

У 1714 р. герцог Вільгельм Ернест підвищує Й. С. Баха на посаді: композитор одержує чин концертмейстера і за сумісництвом виконує функції віце-капельмейстера, в обов'язки якого входило написання до кожної четвертої неділі по одній духовній кантаті. Приблизно в той час, з березня 1714 p. до кінця 1717 р., композитор створив 35 кантат. Однією з них є Кантата № 12 «Weinen, Klagen, Sorgen, Zagen» (Сльози, Зітхання, Трепет, Горе), написана на текст Соломона Франка в 1714 p. (iї тема згодом, майже через 150 років, стане основою «Варіацій на тему Баха» Ф. Ліста). Кантата № 12 належить до кращих бахівських творів не лише раннього періоду, але й усього доробку композитора. Кантата починається інструментальною синфонією (вступом, прелюдією), у якій соло виконують гобої. Твір сповнений глибоким пасіонним настроєм, для вираження якого Й. С. Бах використовує мотив високої скорботи. Завдяки руху цього мотиву на вузькі, «м’які» інтервали (переважно секунди) й гармонії, скорбота просвітлюється.

Синфонія підводить до другого номера кантати, у якому продовжує розвиватися пасіонний образ. Бах використовує passus duriusculus у концентрованому вигляді в першій частині хору «Сльози, Зітхання...», написаного у формі пасакалії. У хорі Баха 12 варіацій на хроматично низхідну тему. Нагадаємо, що число «12» символізує Отця, Сина і Святого Духа - число 3, які зійшли у видимий світ - число 4. У хоровій партії немає суцільного руху голосів, вокальні «зітхання» поділяються паузами - музично-риторичною фігурою tmesis. Розірваність мелодії передає страх і заціпеніння. Композитор використовує ще одну риторичну фігуру suspiratio. Відмітимо, що друга частина хору зовсім іншого плану - більш жвава, мотетного складу; вона побудована на висхідних оспівуваннях трихордах і тетрахордах. Хор «Сльози, Зітхання...» написаний в найбільш розповсюдженій на той час тричастинній формі da саро. Тональність Бах вибирає f-moll, котра, як відомо, затвердилась у XVII ст. як одна з основних у створенні скорботного образу. Отже, перший хор кантати найповніше відображає коло пасіонних образів Баха, що передаються за допомогою символів. 
Кантата складається із семи частин. У ранніх кантатах їхній об'єм був ще не настільки регламентований, як в лейпцигських. Т. Ліванова (1980) вважає, що поступово Бах все більше проникає «в загальний план кантати, а саме в її музичну драматургію; у різних напрямках шукає засоби, які об'єднують ціле зверх програми, що дається словесним текстом. Частково йому служить для цього хорал...» (c. 32,33$)$. Бах звертається до хоралу як до традиційного стержня духовної музики протягом усього творчого шляху.

Кантату № 12 Бах завершує хоралом «Господь до блага все веде» (B-dur), який починається квартовим ходом. Саме на мотиви, в основі яких інтервал кварти, дібрані головні слова, що символізують стійкість віри, прийняття волі Бога, надію та впевненість. У хоралі кантати № 12 на квартовий хід Бах ставить слово «Господь». В основі кварти число «4», яке у піфагорійців було символом всього відомого й невідомого, символом рівності, справедливості, сили; у єврейському написанні чотири букви має священне ім'я Єдиного Бога - Ієгова. Отже, хорал можна тлумачити як вираження символу віри. У кантаті відбувається рух образів і емоцій «від темряви і глибини жалю до просвітлення, підйому і знаходженню сили духу і стійкості віри», що ще раз підтверджує сотеріологічну теорію.

Після першого хору йдуть без зв'язкових речитативів три арії. Перша «Kreuz und Krone sind verbunden» («Хрест із славою неподільні») тематично перегукується із синфонією (тобто з № 1). Це скорботна лірико-патетична арія з імпровізаційним розвитком інструментальної партії у вільному ритмічному русі. Голос (альт) вступає дещо пізніше та створює поліфонічний дует із солюючим гобоєм. Виникає контраст напруженого загостреного почуття і сил, що його стримують (помірного повільного руху супроводу, твердої врівноваженості цілого). В альтовому голосі весь час поєднується мотиви хреста із figura corta та різноманітними оспівуваннями, оскільки через страждання можна досягнути благодаті.

Скорботній арії альта протиставляється арія баса (Es-dur) - мужньо-рішуча, наповнена сміливим підйомом почуттів. На відміну від попередніх частин, у ній висвітлюється діатоніка. Хроматика й діатоніка - полярні інтонаційні полюси кантати. Вокальний та інструментальний голоси створюють канон, який символізує згідно з текстом - «Я за Христом піду» - «хід». Мелодію Бах подає у висхідному русі музично-риторична фігура anabasis, з початковою квартою, що виражає рух до конкретної цілі, сходження. В арії відбувається передбачення Хоралу кантати. Наступна арія тенора «Сподівайсь, сподівайсь!» акордово-гомофонного складу; у ній висвітлюється музичний матеріал: «За негодою прийде щастя». Композитор у супроводі використовує «ритм блаженства». Арія підводить до заключного хоралу.

Отже, в Кантаті № 12 найбільш концентровано висвітлюються образи скорботи через історичні теми-образи, теми-символи: риторичні фігури passus duriusculus, suspiratio, tmesis, figura corta, інтонацію lamento, мотив хреста. Цей твір Баха можна назвати Кантатою на «Страсті Христа», де образ страждання розкривається як величне, очищаюче почуття.

\section{Висновки}

Завдяки семантичному аналізу музичної мови Й. С. Баха виявлено, що в кантатах пасіонного типу найповніше відобразилася бахівська інтерпретація лютеранства, а саме сотеріологічна теорія, яка розкриває вчення про спасіння. Глибоке витлумачування Бахом євангельських читань дає підстави інтерпретувати кантати як своєрідну проповідь. Кантати пасіонного типу композитор будує за драматургічним принципом «від страждання до благодаті». Бах вдається до комплексу символіки пасіонності; для відтворення болю і мук Христа він часто використовує риторичну фігуру passus duriusculus як символ страждання. Занурення в смислову глибину духовних кантат Й. С. Баха пасіонного типу дає змогу поновому розкрити багатовимірність комплексу одвічних проблем, що сприяють народженню нового сенсу.

Перспективи подальших досліджень убачаємо в семантичному аналізі клавірних творів Й. Баха пасіонного типу, виявленні їхніх духовних інспірацій та в глибокому вивченні музичної мови.

\section{Список використаних джерел}

Берденникова, Е. (2008). Гомилетические традичии духовных кантат И. С. Баха. Музична Україна.

Берченко, Р. Э. (2008). В поисках утраченного смысла: Болеслав Яворский о «Хоромо темперированном клавире». Классика-XXI.

Бодки, Э. (1993). Интерпретаиия клавирных произведений И. С. Баха (А. Е. Майкапар, пер.). Музыка.

Друскин, М. С. (1976). Пассионы и мессы И. С. Баха. Музыка, Ленинградское отделение. 
Друскин, М. С. (1982). Иоганн Себастьян Бах. Музыка.

Заболотная, Н. Г. (2002). Об интонационно-историческом подходе к типологии духовных кантат И. С. Баха. Музичне мистецтво і культура, 3, 233-240.

Ливанова, Т. Н. (1980). Музыкальная драматургия И. С. Баха и ее исторические связи (Ч. 2). Музыка.

Медушевский, В. В. (2003). Предметы осмысления и анализа в музыке и других искусствах. Музичне мистецтвво і культура, 4, 7-15.

Петров, Ю. П. (1993). Символика и диалектика чисел в «Хорошо темперированном клавире» И. С. Баха (I том). Интерпретация клавирных сочинений И. С. Баха, 109, 5-32.

Серенко, С. О. (2004). Художня концепція «Мистецчтва фуги» Й. С. Баха. (Автореферат дисертації кандидата мистецтвознавства). Одеська державна музична академія імені А. В. Нежданової, Одеса.

Форкель, И. Н. (2008). О жизни, искусстве и о произведениях Иоганна Себастьяна Баха (В. Ерохин, пер.). Классика-XXI.

Швейцер, А. (2004). Иоганн Себастьян Бах (X. Стрекаловская, пер.). Классика-XXI.

Шепеленко, Н. (2018). Втілення жанрового канону ораторії у творчості західноєвропейських $і$ вітчизняних композиторів XVII-XXI cmоліть. (Дисертація кандидата мистецтвознавства). Харківський національний університет мистецтв імені І. П. Котляревського, Харків.

Яворский, Б., \& Носина, В. (2009). Сюить Баха для клавира. О символике «Французских сюит» И. С. Баха. Классика-XXI.

Blankenburg, W. (1950). In the Sign of Bach. Concordia Theological Monthly, 5, 366-367.

Blume, F. (1963). Outlines of a New Picture of Bach. Music \& Letters, 44(3), 214-227.

Leahy, A. (1999). The opening chorus of cantata BWV 78, "Jesu, der du meine Seele". Bach, 30(1), 26-41.

\section{References}

Berchenko, R. E. (2008). Vpoiskakh utrachennogo smysla: Boleslav Iavorskii o "Khorosho temperirovannom klavire" [In Search of Lost Meaning: Bolesław Jaworski on "Well-Tempered Clavier"]. Klassika-XXI [in Russian].

Berdennikova, E. (2008). Gomileticheskie traditcii dukhovnykh kantat I. S. Bakha [Homiletic traditions of J. S. Bach's spiritual cantatas]. Muzychna Ukraina [in Russian].

Blankenburg, W. (1950). In the Sign of Bach. Concordia Theological Monthly, 5, 366-367 [in English].

Blume, F. (1963). Outlines of a New Picture of Bach. Music \& Letters, 44(3), 214-227 [in English].

Bodki, E. (1993). Interpretatciia klavirnykh proizvedenii I. S. Bakha [Interpretation of the keyboard works by J. S. Bach] (A. E. Maikapar, Trans.). Muzyka [in Russian].

Druskin, M. S. (1976). Passiony i messy I. S. Bakha [Passions and Masses by J. S. Bach]. Muzyka, Leningrad branch [in Russian].

Druskin, M. S. (1982). Iogann Sebastian Bakh [Johann Sebastian Bach]. Muzyka [in Russian].

Forkel, J. N. (2008). O zhizni, iskusstve i o proizvedeniiakh Ioganna Sebastiana Bakha [On Johann Sebastian Bach's Life, Genius, and Works] (V. Erokhin, Trans.). Klassika-XXI [in Russian].

Iavorskii, B., \& Nosina, V. (2009). Siuity Bakha dlia klavira. O simvolike "Frantcuzskikh siuit" I. S. Bakha [Bach Suite for Clavier. About the Symbolism of "French Suites" by J. S. Bach]. Klassika-XXI [in Russian].

Leahy, A. (1999). The opening chorus of cantata BWV 78, "Jesu, der du meine Seele". Bach, 30(1), 26-41 [in English].

Livanova, T. N. (1980). Muzykalnaia dramaturgiia I. S. Bakha i ee istoricheskie sviazi [J. S. Bach's Musical Dramaturgy and Its Historical Relations] (Pt. 2). Muzyka [in Russian].

Medushevskii, V. V. (2003). Predmety osmysleniia i analiza v muzyke i drugikh iskusstvakh [Subjects of Comprehension and Analysis in Music and Other Arts]. Music art and culture, 4, 7-15 [in Russian].

Petrov, Iu. P. (1993). Simvolika i dialektika chisel v "Khorosho temperirovannom klavire" I. S. Bakha (I tom) [Symbolism and Dialectics of Numbers in J. S. Bach's "Well-Tempered Clavier" (I volume)]. Interpretatciia klavirnykh sochinenii I. S. Bakha, 109, 5-32 [in Russian].

Schweitzer, A. (2004). Iogann Sebastian Bakh [Johann Sebastian Bach] (Kh. Strekalovskaia, Trans.). Klassika-XXI [in Russian].

Serenko, S. O. (2004). Khudozhnia kontseptsiia "Mystetstva fuhy" Y. S. Bakha [The Artistic Concept of "Fugue Art" by J. S. Bach]. (Abstract of PhD Dissertation). Odesa State A.V. Nezhdanova Academy of Music, Odesa [in Ukrainian].

Shepelenko, N. (2018). Vtilennia zhanrovoho kanonu oratorii u tvorchosti zakhidnoievropeiskykh $i$ vitchyznianykh kompozytoriv XVII-XXI stolit [Incarnation of the Oratory Genre Canon in the Works of Western European and National Composers of the $17^{\text {th }}-21^{\text {st }}$ Centuries]. (PhD Dissertation). Kharkiv National I. P. Kotlyarevsky University of Arts, Kharkiv [in Ukrainian]. 
Zabolotnaia, N. G. (2002). Ob intonatcionno-istoricheskom podkhode k tipologii dukhovnykh kantat I. S. Bakha [On the Intonational-historical Approach to the Typology of J. S. Bach's Spiritual Cantatas]. Music art and culture, 3, 233240 [in Russian].

Стаття надійшла до редакиії 14.04.2020

\begin{tabular}{r|l} 
СЕМАНТИКА МУЗЫКАЛЬНОГО & Боршуляк Алена Мирославовна \\
ЯЗЫКА ДУХОВНЫХ КАНТАТ & Кандидат искусствоведения, \\
И. С. БАХА ПАССИОННОГО ТИПА & стариий преподаватель, \\
Каменеи-Подольский национальный \\
университет имени Ивана Огенка, \\
Каменеи-Подольский, Украина
\end{tabular}

Цель статьи - проанализировать семантические аспекты духовных кантат И. С. Баха пассионного типа, выявить и раскрыть их смысловую глубину и философско-религиозные инспирации. Методология исследования базируется на применении фундаментальных общенаучных методов познания, а также специальных музыковедческих методов, в частности аналитического при изучении научной литературы; жанрово-стилевого и историко-культурологического, которые способствуют установлению закономерностей развития и специфики жанра кантаты как целостного художественного объекта; герменевтического метода, который помог понять философскую глубину баховских кантат. Семантический анализ выступает как один из главных и наиболее перспективных методов расшифровки смысловых структур духовных кантат Баха пассионного характера. Научная новизна заключается в раскрытии семантических аспектов духовных кантат Й. С. Баха пассионного типа как носителей сотериологической теории, которая проявляется музыкально-риторическими фигурами и символикой, в расширении представлений о символикориторических принципах мышления композитора. Выводы. В результате семантического анализа музыкального языка духовных кантат Й. С. Баха обнаружено, что в кантатах пассионного типа наиболее полно отразилась баховская интерпретация лютеранства, а именно сотериологическая теория, раскрывающая учение о спасении. Доказано, что кантаты пассионного типа композитор строит по драматургическому принципу «от страдания к благодати». Бах применяет комплекс символики пассионности; для воспроизведения боли и мучений Христа он часто использует риторическую фигуру passus duriusculus как символ страдания. Выяснено, что погружение в смысловую глубину духовных кантат И. С. Баха пассионного типа позволяет по-новому раскрыть многомерность комплекса извечных проблем, которые способствует рождению нового смысла.

Ключевые слова: семантика; музыкальная символика; принцип мышления; пассионность; сетериологическая теория

\author{
SEMANTICS OF THE MUSICAL $\mid$ Alona Borshuliak \\ LANGUAGE OF J. S. BACH'S SPIRITUAL $P h D$ in Art Studies, Senior Lecturer, \\ CANTATAS OF THE PASSION TYPE Kamianets-Podilskyi Ivan Ohiienko National University, \\ Kamianets-Podilskyi, Ukraine
}

The purpose of the article is to analyse the semantic aspects of J.S. Bach's passion cantatas, identify and reveal their semantic depth, philosophical and religious inspiration. The research methodology is based on the application of fundamental general scientific methods of cognition, as well as special musicological methods, in particular, analytical in the study of scientific literature; genre and style, historical and cultural methods, which contribute to the establishment of patterns of development and particularity of the cantata genre as a complete artistic object; hermeneutic method, which helped to comprehend the true philosophical meaning of the Bach's cantatas. Semantic analysis emerges as one of the main and the most promising methods for deciphering the semantic structures of the Bach's spiritual cantatas. The scientific novelty is to reveal the semantic aspects of J.S. Bach's spiritual cantatas of the passion type as carriers of soteriological theory, which are manifested by musical rhetorical figures and symbolism, to promote better understanding of symbolic and rhetoric principles of the composer's artistic thinking. Conclusions. Semantic analysis of the musical language of J. S. Bach's spiritual cantatas has demonstrated that in the passion cantatas Bach's interpretation of Lutheranism, namely the soteriological theory that reveals the doctrine of salvation, is reflected to the highest degree. It can be concluded that 
the composer builds his cantatas of the passion type according to the dramatic principle "from suffering to grace". Johann Sebastian Bach applies a whole range of passion symbols. He often uses the rhetorical figure of passus duriusculus as a symbol of suffering to reproduce the pain and torment of Christ. It has been found out that immersion in the spiritual depth of J. S. Bach's spiritual cantatas of the passion type gives ground to re-discover the multidimensionality of the complex of age-old questions that contribute to the emergence of new meaning.

Keywords: semantics; musical symbolism; principle of thinking; passion; soteriological theory 